This item was submitted to Loughborough's Research Repository by the author.

Items in Figshare are protected by copyright, with all rights reserved, unless otherwise indicated.

\title{
Electrosynthesis of cyclic carbonates from epoxides and atmospheric pressure carbon dioxide
}

PLEASE CITE THE PUBLISHED VERSION

http://dx.doi.org/10.1039/c1cc15467b

PUBLISHER

(C) Royal Society of Chemistry

VERSION

AM (Accepted Manuscript)

LICENCE

CC BY-NC-ND 4.0

REPOSITORY RECORD

Buckley, Benjamin R., Anish P. Patel, and K.G.U. Wijayantha. 2019. "Electrosynthesis of Cyclic Carbonates from Epoxides and Atmospheric Pressure Carbon Dioxide”. figshare. https://hdl.handle.net/2134/13585. 
This item was submitted to Loughborough's Institutional Repository (https://dspace.lboro.ac.uk/) by the author and is made available under the following Creative Commons Licence conditions.

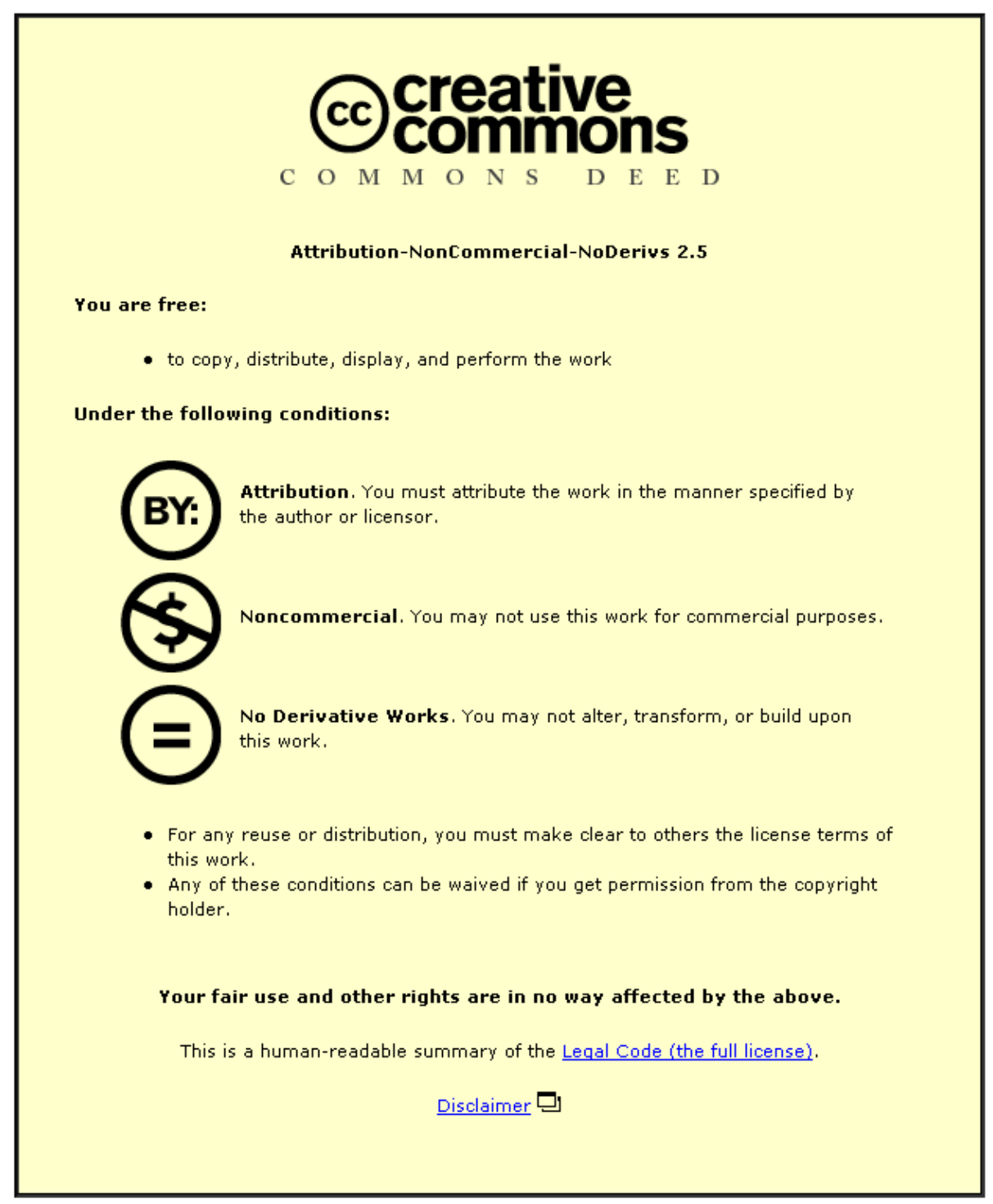

For the full text of this licence, please go to: http://creativecommons.org/licenses/by-nc-nd/2.5/ 


\title{
Electrosynthesis of Cyclic Carbonates from Epoxides and Atmospheric Pressure Carbon Dioxide $\uparrow$
}

\author{
Benjamin R. Buckley*, Anish P. Patel and K. G. Upul Wijayantha* \\ Received (in XXX, XXX) Xth XXXXXXXXX 20XX, Accepted Xth XXXXXXXXX 20XX \\ s DOI: 10.1039/b000000x
}

The use of $\mathrm{CO}_{2}$ for the preparation of value-added compounds has dramatically increased due to increased global warming concerns. We herein report the first example of a direct copper cathode/magnesium anode system that effectively converts 10 epoxides and carbon dioxide to cyclic carbonates under mild electrochemical conditions at atmospheric pressure.

Carbon dioxide is arguably the main contributor to the increased concentration of gases within the atmosphere, in fact since the dawn of the industrial revolution $\mathrm{CO}_{2}$ concentration within the 15 atmosphere has annually increased. ${ }^{1}$ The main cause being identified as the combustion of fossil fuels. Methods that involve reducing the amount of $\mathrm{CO}_{2}$ released into the atmosphere from industrial processes are therefore of significant value. ${ }^{2}$ Current commercial methods involve $\mathrm{CO}_{2}$ capture via absorption using 20 amine based materials post combustion. ${ }^{3}$ Pre-combustion methods also exist in which fuel is firstly converted into $\mathrm{H}_{2}$ and $\mathrm{CO}_{2}$ followed by a capture process. Once captured storage of $\mathrm{CO}_{2}$ is achieved by storing it in unused oil/gas wells or under the ocean. This is a highly energy intesive process and unlike other waste 25 streams $\mathrm{CO}_{2}$ has a variety of possible uses such as a $\mathrm{C} 1$ building block in organic synthesis. ${ }^{4,5}$

To chemists carbon dioxide presents itself as a cheap, non-toxic and highly abundant carbon source, and if effectively activated can allow for carboxylation of organic molecules. Therefore fixation of ${ }_{30} \mathrm{CO}_{2}$ into organic molecules is an area of increasing interest and offers a much more environmentally sound alternative to current storage solutions. ${ }^{6}$ Currently, the greatest obstacle for establishing industrial processes based on $\mathrm{CO}_{2}$ as a raw material is that in general a large energy input is required to transform $\mathrm{CO}_{2}$

35 There are several useful products which can be prepared from $\mathrm{CO}_{2}$, for example polycarbonates which are also synthesised from epoxides and $\mathrm{CO}_{2}$ are commercially important as they have several applications, for example as eyewear lenses and exterior automotive components. ${ }^{7}$ Perhaps the two most effective solutions 40 have been reported independently by Coates and Lee. Coates zinc

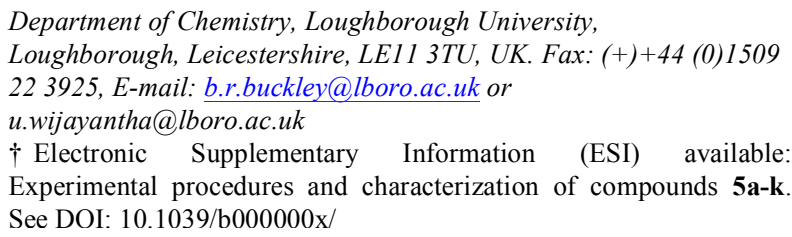

based catalyst 1 has been employed in the copolymerisation of cyclohexene oxide and $\mathrm{CO}_{2}{ }^{8}$ and Lee's salen cobalt catalyst $\mathbf{2}$ has been used in the copolymerisation of propylene oxide and $\mathrm{CO}_{2}$ (Figure 1). ${ }^{9}$ Cyclic carbonates, which are also produced from 45 epoxides and $\mathrm{CO}_{2}$, are widely used in the manufacture of products including solvents, paint-strippers, biodegradable packaging, as well as having other applications in the chemical industry. ${ }^{10}$ Again, however, these processes do require high energy input, including high temperatures, high pressures and the use of purified carbon 50 dioxide.

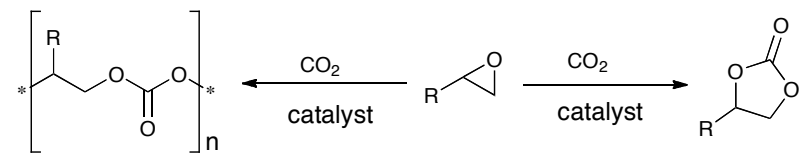

$$
\text { Polycarbonate Epoxide Cyclic carbonate }
$$

Scheme 1. Current processes for $\mathrm{CO}_{2}$ incorporation into epoxides.

There are a plethora of methods for the formation of cyclic carbonates from epoxides and $\mathrm{CO}_{2}{ }^{11}$ but recent efforts have been 55 focused on the development of catalytic systems which are able to transform epoxides to cyclic carbonates at temperatures below 100 ${ }^{\circ} \mathrm{C}$ and at atmospheric pressure. Currently the only successful system is that reported by North and co-workers which employs a bimetallic salen complex such as $\mathbf{3}$ (Figure 1) and ${ }_{60}$ tetrabutylammonium bromide as a co-catalyst, ${ }^{12}$ although later developments have incorporated the co-catalyst into the salen substructure. $^{12 \mathrm{c}}$

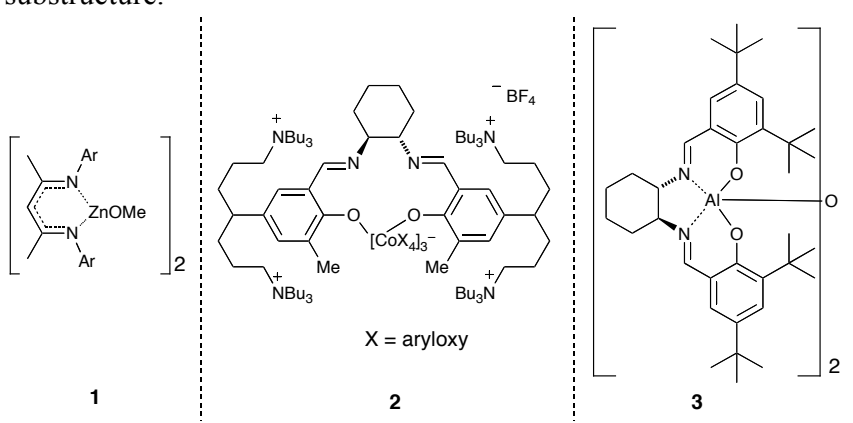

Fig. 1. Current catalysts for $\mathrm{CO}_{2}$ incorporation into epoxides

${ }_{65}$ We were interested in developing a low energy alternative in line with our current research portfolio aimed at electrosynthesis ${ }^{13}$ coupled with semiconductor photoelectrodes to drive light assisted electrosynthetic reactions. ${ }^{14}$ We were therefore attracted to the possibility of employing an electrosynthetic system as this type of 
process could be designed to be cost neutral in terms of energy consumption if combined with a suitable solar powered energy source. Duñach has previously reported the electrochemical carboxylation of epoxides using a nickel(II) cyclam complex, ${ }^{15}$ 5 and in a related process Yuan and co-workers have reported an electrochemical system using high $\mathrm{CO}_{2}$ pressures. ${ }^{16}$ Both of these systems unfortunately have several drawbacks, including expensive potentially toxic catalysts, non-user friendly solvents and in the latter case high $\mathrm{CO}_{2}$ pressures.

10 We believed that it should be possible to deliver a step change in this technology by the development of an electrochemical system which is easy to set up, cheap, reliable, requires no expensive catalysts, runs under atmospheric $\mathrm{CO}_{2}$ pressures and at ambient temperatures. In order to achieve this goal we set about screening a 15 range of electrode materials for the electrosynthetic incorporation of $\mathrm{CO}_{2}$ into our test substrate styrene oxide 4a (Table 1). The reactions were run in a single compartment cell, with acetonitrile as solvent, tetrabutylammonium bromide as electrolyte and $60 \mathrm{~mA}$ current. We were delighted to find that good to excellent 20 conversions to cyclic carbonate could be achieved under a variety of conditions (Table 1). Excellent conversion to cyclic carbonate 5a was achieved using the copper cathode/magnesium anode combination (Table 1 entry 1 ). It is important to note that in the absence of applied current we observed little to no cyclic carbonate ${ }_{25}(3 \%)$ and only recovered unreacted epoxide. ${ }^{17} \mathrm{We}$ also did not observe the formation of any polymeric materials from the possible competing polycarbonate reaction or any other side products that have previously been observed for the corresponding reactions carried out at high temperature and/or pressure. ${ }^{18-19}$

30 Table 1 Electrode screening ${ }^{\mathrm{a}}$

\begin{tabular}{|c|c|c|c|}
\hline 4 & & & $5 a$ \\
\hline Entry & Cathode & Anode & Conv. $(\%)^{b, c}$ \\
\hline 1 & $\mathrm{Cu}$ & $\mathrm{Mg}$ & $>99$ (3) \\
\hline 2 & Steel & $\mathrm{Mg}$ & 75 \\
\hline 3 & Graphite & $\mathrm{Mg}$ & 80 \\
\hline 4 & $\mathrm{Cu}$ & $\mathrm{Al}$ & 75 \\
\hline 5 & $\mathrm{Cu}$ & $\mathrm{Sn}$ & 10 \\
\hline 6 & $\mathrm{Cu}$ & $\mathrm{Zn}$ & 5 \\
\hline
\end{tabular}

${ }^{a}$ General conditions: $\mathrm{CO}_{2}$ ( $1 \mathrm{~atm}$, balloon), $\mathrm{Bu}_{4} \mathrm{NBr}$ (2.0 eq.), $\mathrm{MeCN}$, single compartment cell, $60 \mathrm{~mA}, 7 \mathrm{~h} \mathrm{rt}, 12 \mathrm{~h} 50{ }^{\circ} \mathrm{C}$; ${ }^{\mathrm{b}}$ Conversion evaluated from the ${ }^{1} \mathrm{H}$ NMR spectrum by integration of epoxide vs cyclic carbonate peaks; ${ }_{35}{ }^{\mathrm{c}}$ The number in parenthesis refers to the conversion from the reaction carried out in the absence of electrolysis.

We next turned our attention to optimizing this mild system (Table 2), we found that high conversion to cyclic carbonate could still be achieved if we reduced the amount of tetrabutylammonium 40 bromide to 1.0 equivalents (it is important to note here that we typically recover $90-95 \%$ of this material after the reaction by precipitation with EtOAc), however, below this level we observed only a $80 \%$ conversion (Table 2 , entry 3 ). We also found that the use of tetrabutylammonium bromide is essential for the reaction to

45 proceed, if we replaced the bromide counter-ion with tetrafluoroborate then we observed only $17 \%$ conversion to cyclic carbonate (Table 2 , entry 5). The reactions can be carried out at room temperature $(77 \%$ conversion after $6 \mathrm{~h}$, Table 2 , entry 7$)$, however, for convenience mild heating to $50^{\circ} \mathrm{C}$ is employed (Table ${ }_{50} 2$, entry 6); A combination of heating $\left(50^{\circ} \mathrm{C}\right)$ and electrolysis $(60$ $\mathrm{mA}$ ) affords the cyclic carbonate $\mathbf{2 a}$ in $99 \%$ conversion and $96 \%$ isolated yield. Reduced reaction times, for example, $3.5 \mathrm{~h}$ results in only $76 \%$ conversion (Table 2 , entry 8 ).

Table 2 Optimization studies ${ }^{\mathrm{a}}$

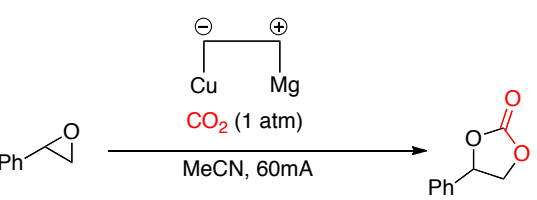

\begin{tabular}{ccccc} 
4a & \multicolumn{3}{c}{ 5a } \\
\hline Entry & $\begin{array}{c}\text { Supporting } \\
\text { Electrolyte (equiv.) }\end{array}$ & $\mathrm{T}\left({ }^{\circ} \mathrm{C}\right)$ & $\mathrm{t} \mathrm{(h)}$ & $\begin{array}{c}\text { Conv. } \\
(\%)^{\mathrm{b}}\end{array}$ \\
\hline 1 & $\mathrm{Bu}_{4} \mathrm{NBr}(2.0)$ & $7 \mathrm{~h} \mathrm{rt}, 12 \mathrm{~h} 50{ }^{\circ} \mathrm{C}$ & 19 & $>99$ \\
2 & $\mathrm{Bu}_{4} \mathrm{NBr}(1.0)$ & $7 \mathrm{~h} \mathrm{rt}, 12 \mathrm{~h} 50^{\circ} \mathrm{C}$ & 19 & 98 \\
3 & $\mathrm{Bu}_{4} \mathrm{NBr}(0.5)$ & $7 \mathrm{~h} \mathrm{rt}, 12 \mathrm{~h} 50^{\circ} \mathrm{C}$ & 19 & 80 \\
4 & $\mathrm{Bu}_{4} \mathrm{NBr}(1.0)$ & $25^{\circ} \mathrm{C}$ & 6 & 77 \\
5 & $\mathrm{Bu}_{4} \mathrm{NPF}_{6}(1.0)$ & $50^{\circ} \mathrm{C}$ & 6 & 17 \\
6 & $\mathrm{Bu}_{4} \mathrm{NBr}(1.0)^{\mathrm{c}}$ & $50^{\circ} \mathrm{C}$ & 6 & 99 \\
& & & & $(96)$ \\
7 & $\mathrm{Bu}_{4} \mathrm{NBr}(1.0)$ & $25^{\circ} \mathrm{C}$ & 6 & 77 \\
8 & $\mathrm{Bu}_{4} \mathrm{NBr}(1.0)$ & $50^{\circ} \mathrm{C}$ & 3.5 & 76 \\
\hline
\end{tabular}

${ }^{a}$ General conditions: $\mathrm{Cu}$ cathode, $\mathrm{Mg}$ anode, $\mathrm{CO}_{2}$ (1 atm, balloon), $\mathrm{MeCN}$, single compartment cell, $60 \mathrm{~mA} ;{ }^{\mathrm{b}}$ Conversion evaluated from the ${ }^{1} \mathrm{H}$ NMR spectrum by integration of epoxide vs cyclic carbonate peaks, isolated yield after column chromatography is shown in parenthesis; ${ }^{\mathrm{c}}$ On average 90 ${ }_{60} 95 \%$ of the $\mathrm{Bu}_{4} \mathrm{NBr}$ is recovered after each reaction by precipitation with EtOAc.

With our optimized conditions in hand we screened the applicability of this system over a range of substrate types (Table $3)+$. We were delighted to find that excellent yields of cyclic ${ }_{65}$ carbonates were observed including electron rich and poor aromatic systems and a range of aliphatic epoxides were also effectively converted to the corresponding cyclic carbonate (these yields represent some of the highest reported to date). Sensitive functionalized substrates such as $\mathbf{4 i - k}$, are also tolerated under the 70 reaction conditions affording excellent yields of the corresponding cyclic carbonates $\mathbf{5 i - k}$.

In order to explore the mild nature of these reaction conditions we were interested in the applicability of this system to enantiopure epoxides. Application of our optimized conditions to 75 the $\mathrm{CO}_{2}$ incorporation of $(S)$-styrene oxide afforded the cyclic carbonate in excellent yield (97\%) with retention of configuration and only a slight loss of optical purity (99.5:0.5 e.r. to $98.6: 1.4$ e.r.).

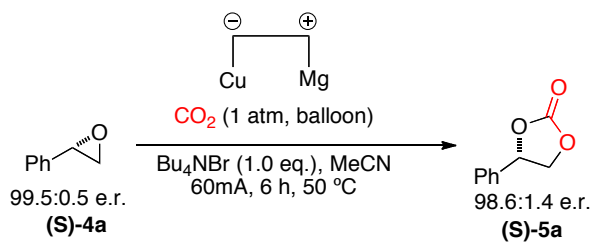

${ }_{80}$ Scheme 2. Elecrocarboxylation of $(S)$-styrene oxide to afford the enantiomerically pure cyclic carbonate with retention of configuration.

In conclusion we have developed a powerful new tool in the combat against $\mathrm{CO}_{2}$ emissions for the synthesis of value added compounds. This process is one of only a handful of approaches 85 that allow this reaction to proceed at atmospheric pressure and at 


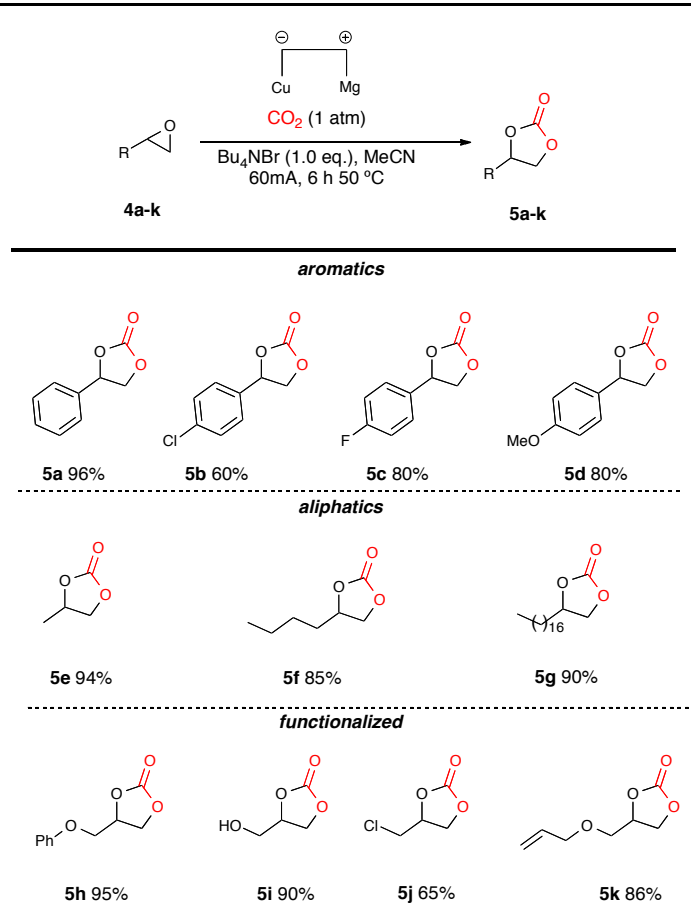

${ }^{a}$ General conditions: $\mathrm{CO}_{2}, \mathrm{Cu}$ cathode, $\mathrm{Mg}$ anode, $\mathrm{Bu}_{4} \mathrm{NBr}$ (2.0 equiv.), $\mathrm{MeCN}$, single compartment cell, $60 \mathrm{~mA}, 6 \mathrm{~h} 50{ }^{\circ} \mathrm{C} ;{ }^{\mathrm{b}} \mathrm{On}$ average $90-95 \%$ of ${ }_{5}$ the $\mathrm{Bu}_{4} \mathrm{NBr}$ is recovered after each reaction by precipitation with EtOAc; ${ }^{\mathrm{c}}$ Conversion evaluated from the ${ }^{1} \mathrm{H}$ NMR spectrum by integration of epoxide vs cyclic carbonate peaks; ${ }^{\mathrm{d}}$ isolated yield after column chromatography; ${ }^{\mathrm{e}}$ Reaction ran for $8 \mathrm{~h}$

ambient-mild temperatures. ${ }^{11,15}$ The yields obtained are 10 comparable or better than those already reported in the area and our approach benefits from not employing an additional catalyst into the reaction, which in some cases can be toxic or expensive. The equipment required to perform this $\mathrm{CO}_{2}$ incorporation reaction is cheap and should be readily available in any undergraduate 15 teaching facility i.e. copper wire, magnesium ribbon and a power supply. We are currently looking at the mechanism (early indications show that it does not involve $\mathrm{MgBr}_{2}{ }^{20}$ but may well be related to that postulated by North and co-workers) ${ }^{12 \mathrm{e}}$ and scalability of this process ${ }^{21}$ as well as applications of $\mathrm{CO}_{2}$ 20 incorporation towards other types of organic molecules and the development of a self-contained solar driven process.

\section{Notes and references}

$\$$ Representative procedure for the synthesis of phenyl ethylene carbonate $5 \mathrm{a}:{ }^{22}$ Styrene oxide $(0.12 \mathrm{~g}, 1.0 \mathrm{mmol})$ and $\mathrm{CO}_{2}$ (balloon) in acetonitrile $25(150 \mathrm{~mL})$ were electrolysed (constant current: $60 \mathrm{~mA})$ for $6 \mathrm{~h}$ in a single compartment cell (Mg anode and Copper(0) cathode) containing $\mathrm{Bu}_{4} \mathrm{NBr}$ $(0.32 \mathrm{~g}, 1.0 \mathrm{mmol})$ as supporting electrolyte at $50^{\circ} \mathrm{C}$. On completion the reaction mixture was washed with aqueous $0.1 \mathrm{M} \mathrm{HCl}(50 \mathrm{~mL})$ followed by extraction with $\mathrm{Et}_{2} \mathrm{O}(3 \times 35 \mathrm{~mL})$. The combined organic extracts were 30 then dried over $\mathrm{MgSO}_{4}$ and evaporated under reduced pressure to afford a amber oil, which was suspended in EtOAc $(100 \mathrm{~mL})$. After $1 \mathrm{~h}$ the precipitated $\mathrm{Bu}_{4} \mathrm{NBr}(0.30 \mathrm{~g}, 95 \%)$ was removed by filtration and the solvent evaporated under reduced pressure to afford an amber oil. This crude material was purified by column chromatography on silica gel 35 eluting with ethyl acetate:light petroleum. Colourless solid $(0.157 \mathrm{~g}, 96 \%)$.

1 (a) H. Yang, Z. Xu, M. Fan, R. Gupta, R. B. Slimane, A.E. Bland, I. Wright, J. Environ. Sciences, 2008, 20, 14-27; (b) The 2010 BP statistical review of

(http://www.bp.com/statisticalreview)

world

energy

2 D. P Schrag, Science 2007, 315, 812-813

3 P. H. M Feron, C. A. Hendriks, Oil \& Gas Science and TechnologyRev. IFP., 2005, 60, 451-459.

4 T. Sakakura, J.-C. Choi, H. Yasuda, Chem. Rev. 2007, 107, 23652387.

5 M. Aresta, A. Dibenedetto, Dalton Trans. 2007, 2975-2992.

6 R. Angamuthu, P. Byers, M. Lutz, A. L. Spek, E. Bouwman, Science 2010, 327, 313-315.

7 V. Serini, "Polycarbonates" in Ullmann's Encyclopedia of Industrial

50 Chemistry, Wiley-VCH, Weinheim, 2000, doi:10.1002/14356007.a21_207.

8 D. R. Moore, M. Cheng, E. B. Lobkovsky, G. W. Coates, Angew. Chem. 2002, 114, 2711-2714; Angew. Chem. Int. Ed. 2002, 41, 25992602.

559 J. Yoo, S. J. Na, H. C. Park, A. Cyriac, B. Y. Lee, Dalton Trans. 2010, 39, 2622-2630.

10 M. North, R. Pasquale, C. Young, Green Chem., 2010, 12, 1514-1539.

11 For some recent reviews and articles on high pressure and/or temperature approaches to cyclic carbonates see: (a) I. Omae, Catal.

60 Today 2006, 115, 33-52; (b) J. H. Clements, Ind. Eng. Chem. Res. 2003, 42, 663-674; (c) M. Yoshida, M. Ihara, Chem. Eur. J. 2004, 10, 2886-2893; (d) R. Srivastava, T. H. Bennur, D. Srinivas, J. Mol. Catal. A 2005, 226, 199-205; (e) R. Zevenhoven, S. Eloneva, S. Teir, Catal. Today 2006, 115, 73-79; (f) T. Sakakura, K. Kohno, Chem. Commun. 2009, 1312-1330; (g) J. Sun, S.-i. Fujita, M. Arai, J. Organomet. Chem. 2005, 690, 3490-3497; (h) W.-L. Dai, S.-L. Luo, S.-F. Yin, C.T. Au, Appl. Catal. A 2009, 366, 2-12; (j) R. L. Paddock, S. T. Nguyen J. Am. Chem. Soc. 2001, 123, 11498-11499.

12 (a) J. Meléndez, M. North, R. Pasquale, Eur. J. Inorg. Chem., 2007, 3323-3326; (b) M. North, R. Pasquale, Angew. Chem. 2009, 121, 2990-2992; Angew. Chem., Int. Ed. 2009, 48, 2946-2948; (c) J. Meléndez, M. North, P. Villuendas, Chem. Commun. 2009, $2577-$ 2579; (d) M. North, P. Villuendas, C. Young, Chem. Eur. J. 2009, 11454-11457; (e) W. Clegg, R. W. Harrington, M. North, R. Pasquale, Chem. Eur. J. 2010, 16, 6828-6843: (f) I. S. Metcalfe, M. North, R. Pasquale, A. Thursfield, Energy Environ. Sci., 2010, 3, 212-215.

13 P. C. B. Page, F. Marken, C. Williamson, Y. Chan, B. R. Buckley, D. Bethell, Adv. Synth. Catal. 2008, 350, 1149-1154.

14 (a) A. A. Tahir, K. G. U. Wijayantha, J. Photochem. Photobiol. A, 2010, 216, 119-125; (b) A. A. Tahir, K. G. U. Wijayantha, S. SaremiYarahmadi, M. Mazhar, V. McKee, Chem. Mate. 2009, 21, 37633772; (c) K. Tennakone, G. R. R. A. Kumara, K. G. U. Wijayantha, I. R. M. Kottegoda, V. P. S.Perera, M. L. P. Aponsu, J. Photochem. Photobiol. A, 1997, 108, 175-177.

8515 (a) P. Tascedda, E. Duñach, J. Chem. Soc., Chem. Commun., 1995, 43-44; (b) E. Duñach, P. Tascedda, M. Weidmann, E. Dinjus, Appl. Organometal. Chem., 2001, 15, 141-144.

16 Y. Wang, G.-Q. Yuan, Y.-C. Zeng and H.-F. Jiang, Chin. J. Org. Chem., 2007, 27, 1397-1400.

9017 Epoxides dissolved in molten TBAB/TBAI have been converted into cyclic carbonates under atmospheric pressure carbon dioxide, but at elevated temperatures $\left(120^{\circ} \mathrm{C}\right)$ : see V. Calo, A. Nacci, A. Monopoli, A. Fanizzi, Org. Lett., 2002, 4, 2561-2563.

18 For example, isomerisation of the epoxide to ketone and aldehydes or addition of $\mathrm{H}_{2} \mathrm{O}$ to afford the ring opened diol: see J.-Q. Wang, X.-D. Yue, F. Cai, L.-N. He, Catal. Commun. 2007, 8, 167-172.

$19 \mathrm{GC} / \mathrm{MS}$ and ${ }^{1} \mathrm{H},{ }^{13} \mathrm{C}$ NMR data revealed only the reaction products and $\mathrm{Bu}_{4} \mathrm{NBr}$.

20 In a independent reaction addition of $\mathrm{MgBr}_{2}$ to the reaction without electrolysis resulted in complete recovery of starting materials.

21 The electrode materials required for large scale applications are currently commercially available. $\mathrm{Mg}$ anodes are used in the protection of ship hulls. See for example: http://www.corrpro.co.uk/pdf/Anodes/Magnesium/MagnesiumAnodes.pdf

22 Spectroscopic data for phenyl ethylene carbonate 5a were consistent with those reported in the literature: see J.-L. Jiang, F. Gao, R. Hua, X. Qiu, J. Org. Chem. 2005, 70, 381-383. 